\title{
Biochemical changes in Tomato plant by AM fungi
}

\section{Rakesh Pipralia* and Anil Vyas}

Department of Botany, Jai Narain Vyas University, Jodhpur- 342 001, (Raj.) India.

Received: 9/13/2017; Accepted:11/19/2017

\begin{abstract}
The effectiveness of six arbuscular mycorrhizae species, Acaulospora morrowae Spain \& Schenck, Gigaspora margarita Becker \& Hall, Glomus fasciculatum (Thaxt. Sensu. Gerd.) Gerd. \& Trappe, G. macrocarpum Tul. \& Tul. Scutellospora calospora (Nicol. \& Gerd.) Walker \& Sanders, and Sclerocystis rubiformis Gerd. \& Trappe, collected from rhizosphere soils of Tomato, was measured for enrichment of PRO, PPO activities and protein, phenolic, and catechin contents in this vegetable plant. Culturing was done under green house and studied were performed ninety days after inoculation. All fungi showed favorable effects, with $S$. calospora being the most promoting of all biochemical parameters.
\end{abstract}

Keywords: Peroxidase; Polyphenol oxidase Mycorrhizae; AM.

\section{Introduction}

Tomato is an important usable plant of the arid and semi arid regions of Asia. It is a source of fuel and fodder, besides producing the nutritious edible fruit known as pilu. The various enzymatic activities increased by YAM fungi which in results the physiological changes in plants 1. Nitrogen is an important nutrient, whose availability is most likely limiting to plant growth ${ }^{2}$. Nitrogen uptake increasing by VA mycorrhizae has been well recognized ${ }^{3}$. Peroxidase and polyphenol oxidase both are important components of the defense mechanism of plants against pathogens. In plant disease resistance Phenols and catechins play an important role (Protein levels in leaves determine the nutritive value). Regarding of these benefits, this investigation was undertaken to evaluate the efficiency of different AM species towards biochemical changes in Tomato.

\section{Materials and Methods}

In total various 6 VAM species vir. Gigaspora margarita, Glomus fasciculatum (Thaxt. Sensu. Gerd.), G. macrocarpum Sclerocystis rubiformis, Acaulospora morrowae, and Scutellospora calospora (Nicol. \& Gerd.) were studied. Their samples were screened by method of wet sieving and decanting (Gerdemann and Nicolson, 1963) including soil sources from the rhizosphere of Tomato ${ }^{4}$. The fungi were recognized as subsequent the synoptic key of Trappe 5 and the guidelines of Schenck and Perez ${ }^{6}$ and preserved in various pot cultures of Cenchrus ciliaris. Later pot cultures of the variousSoil samples with contaminated root segments of C. ciliaris, were used as inoculum. It was estimated that Approx $20 \mathrm{~g}$ of inoculum poses more than 5,000 spores these infected root segments were inoculated in all $18-\mathrm{cm}$ diameter pot containing sterilized soil. The soil was sandy with other parameter as follows$\mathrm{pH}$ of 8.2, phosphate approx. $2.30 \mathrm{ppm}$, total Nitrogen of approx $2.15 \mathrm{ppm}$, where as the content of Carbon (organic) was observed as of approx 0.12 percent. 5 surface sterilized seeds (sterilized by $0.1 \% \mathrm{Hgcl}_{2}$ solution) of Tomato were sown per pot. These containers were kept in preserved in a glass house with the $60 \%$ humidity, temperature was maintained at range of $22-25^{\circ} \mathrm{C}$ and day light was kept upto $12-14 \mathrm{~h}$ day. Here to be noted that Container without VAM inoculum served as control.

\footnotetext{
${ }^{*}$ Corresponding Author:

Mr. Rakesh Pipralia,

Department of Botany, Jai Narain Vyas University,

Jodhpur- 342 001, (Raj.), India.

E-mail: rkpipralia@gmail.com
}

These containers were treated with $1 / 2$ strength Hoaglands, nutrient solution every 2 weeks. Followed which seedlings were thinned to one per container. There were ten containers per treatment. After 6 months these treated plants were harvested for examination. Phosphorus was measured by the vanadomolybdate method 7. Soluble proteins in leaves and roots were examined by the comassive blue method 8 and total phenols were calculated by Folin ciocalteu's reagent ${ }^{9}$. For measurement of catechins, root samples were steamed and dried to constant weight. Catechins extracted in $50 \%$ acetone were estimated by measuring absorbance by the yellow colour that developed with diazotized sulphanilamide at $430 \mathrm{~nm}^{10}$

\section{PRO and PPO Assay}

Various sections of root were homogenized in $0.1 \mathrm{M}$ phosphate buffer, with $7 \mathrm{pH}$, in a pre-chilled mortar and pestle at $4^{\circ} \mathrm{C}$. The homogenate was centrifuged at $5 \mathrm{~K}$ rpm for $15 \mathrm{~min}$ and the supernatant was used for enzyme assay. Peroxidase activity was calculated by incubating the enzyme with guaiacol and hydrogen peroxide ${ }^{11}$. The arbitrary unit of enzyme activity chosen was change in absorbance of $0.001 \mathrm{sec}^{-1}$. Polyphenoloxidase activity was measured at $420 \mathrm{~nm}$, using the method of Mahadevan ${ }^{12}$. The activity is presented in terms of absorbance of 100 $\mathrm{mg}$ (fresh weight of tissues) ${ }^{-1}$. At harvest time 10 samples of each treatment were studied.

\section{Results and Discussion}

Peroxidase and polyphenoloxidase activities in roots of Tomato is increased by AM inoculation. (Table 2). It is assumed that this increased peroxidase activity by AM fungi may be due to an increased P-uptake resultant from the symbiosis relation ${ }^{1}$. Reported lower peroxidase activity in low Phosperous roots than high Phosperous roots. Linear correlation was observed between total phenol accumulation and PPO activity in AM inoculated Tomato roots (Table 2). S. calospora came out to be most active in enhancing phenolic accumulation. The increased phenolic buildup might be due to an increased PPO activity. Accumulation of phenol in VA mycorrhizal plants has been reported ${ }^{13}$. as well as in tissues of a 
variety of plants during pathogenesis ${ }^{14}$. PRO and PPO are important in the defense mechanism against pathogens. Both enzymes are involved in the oxidation of phenolic compounds to quinones, which are presumably toxic to pathogens ${ }^{2}$. The significant increase in PRO and PPO by S. calospora may be noteworthy in protecting this fruit tree from attacking pathogens. Similarly, the increased catechin levels by the AM inoculation (Table 2) may also favour the pathogen defense mechanism of Tomato. Approx 2-fold increase in protein content was found in leaves of Tomato with $S$ calospora (Table 1). The higher protein accumulation in leaves of this plant may be advantageous when used as fodder for animals. Hence this AM endophyte can also improve the nutritive value of Tomato leaves.
Table 1. Variations in soluble protein contents in Tomato esultant from infection by different AM fungi.

\begin{tabular}{lcc}
\multirow{2}{*}{\multicolumn{1}{c}{ Treatment }} & \multicolumn{2}{c}{ Soluble protein $\left(\mathbf{m g ~ g}^{-1} \mathbf{f w}\right)$} \\
\cline { 2 - 3 } & Root & Leaves \\
\hline Acaulospora morrowae & 1.14 & 9.14 \\
Gigaspora margarita & 1.76 & 12.22 \\
Glomus fasciculatum & 1.58 & 11.79 \\
Glomus macrocarpum & 1.51 & 10.46 \\
Sclerocystis rubiformis & 1.42 & 10.17 \\
Scutellospora calospora & 1.92 & 14.02 \\
Control & 0.72 & 7.13 \\
L.S.D. at P $\leq 0.05$ & 0.25 & 2.23 \\
\hline
\end{tabular}

Table 2. Variations in PRO and PPO activities in roots of Tomato due to mycorrhizal colonization.

\begin{tabular}{|c|c|c|c|c|c|}
\hline Treatment & $\begin{array}{c}\text { PRO activity } \\
\text { (Units } \mathrm{mg}^{-1} \text { protein) }\end{array}$ & $\begin{array}{c}\text { PPO activity } \\
\left(\Delta \mathrm{A}_{420} / 100 \mathrm{mg} \text { fw }\right)\end{array}$ & $\begin{array}{c}\text { Total-P } \\
\left(\mathrm{mg} \mathrm{g}^{-1} \mathrm{dw}\right)\end{array}$ & $\begin{array}{l}\text { Total phenol } \\
(\% \mathrm{dw})\end{array}$ & $\begin{array}{c}\text { Catechin } \\
(\% \mathrm{dw})\end{array}$ \\
\hline Acaulospora morrowae & 102.4 & 109.4 & 3.8 & 4.1 & 7.0 \\
\hline Gigaspora margarita & 137.3 & 142.6 & 6.2 & 6.7 & 10.3 \\
\hline Glomus fasciculatum & 120.5 & 130.2 & 5.4 & 6.0 & 9.3 \\
\hline Glomus macrocarpum & 116.2 & 123.3 & 4.9 & 5.4 & 8.4 \\
\hline Sclerocystis rubiformis & 112.4 & 118.5 & 4.3 & 4.9 & 7.9 \\
\hline Scutellospora calospora & 178.0 & 183.6 & 7.6 & 7.9 & 11.2 \\
\hline Control & 86.2 & 92.4 & 3.2 & 3.4 & 6.4 \\
\hline L.S.D. at $\mathrm{P} \leq 0.05$ & 19.5 & 14.2 & 1.2 & 1.2 & 0.5 \\
\hline
\end{tabular}

\section{Conclusion}

The Concluion of this investigation shows inoculation with S calospora can cause elevation of assimilating enzymes most effective in Tomato, which collectively enhance biomass and more highly proteinaceous fruit and make the plant highly resistant to pathogens as a result of increased PPO and PRO activities.

\section{Acknowledgement}

Authors are thankful to Head, Department of Botany, J.N.V. University for providing laboratory facilities.

\section{References}

1. Mathur, $\mathrm{N}$ and Vyas, A. (2016) Survival and establishment of exotic plant species in saline areas of Indian Thar Desert by application of mycorrhizal technology. Asian Journal of Plant Science and Research, 2016, 6(3): 1-6

2. Mathur, N. and A. Vyas. 1995. patterns of peroxidase and polyphenol oxidase Changes in isozme by VAM fungi in roots of Ziziphus species. J. Plant Physiol. 145(4): 498-500.

3. Vyas, M and Vyas, A. (2014)Field Response of Capsicum annum dually inoculated with $\mathrm{AM}$ fungi and PGPR in western Rajasthan.IJRSB.2(3)21-26

4. Gerdemann, J.W. and T.H. Nicolson. 1963. Spores of mycorrhizae Endogone species extracted from soil by wet sieving and decanting. Trans. Br. Mycol. Soc. 46: 235-244.

5. Trappe J.M.1962 Synoptic keys to the genera and species of zygomycetous mycorrhizal fungi. Phytopathology 72 : $1102-1108$
6. Schenck, N.C. and Y. Perez. 1987. Manual for the Identification of VA Mycorrhizal Fungi, pp. 11-14. Shapiro, B.M. and E.R. Stadtman. 1970. Glutamine synthetase (Escherichia). Methods Enzymol. 17A: 910-922.

7. Jackson, M.L. 1973. Soil Chemical Analysis Prentice Hall of Indian Ltd., New Delhi, 574 pp.

8. Bradford, M.M. 1976. A rapid and Sensitive method for the quantitation of microgram quantities of protein utilizing the principle of protein dye binding. Anal. Biochem. 72: 248-254

9. Bray, H.G. and W.V. Thrope. 1954. Estimation of phenols In D. Glick (ed.), Methods of Biochemical Analysis. vol. 1 Interscience Publishing Inc, New York, pp. 27-52.

10. Gulati, A., A. Gulati, S.D. Ravindemath, G. Satyanarayana and D.N. Chakrabarty. 1993. Effect of blister blight of infusion quality in orthodoxtea. Indian Phytopathol. 46(2): 155-159.

11. Racusen, D. and M. Foote. 1965. Protein synthesis in dark grown bean levels. Can. J. Bot. 43: 817-824.

12. Mahadevan, A. 1975. Methods in Physiological Plant Pathology. Sivakami Publication, Madras, India.

13. Krishna, K.R. and D.J. Bagyaraj. 1984. Phenois in mycorrhizal roots of Arachis hypogea. Experientia 40L: 8586.

14. Vidhyasekaran, P. 1989. Basic Research for Crop Disease Management. vol. I and II Delhi. Daya Publishing House.

\section{Cite this article as:}

Rakesh Pipralia and Anil Vyas. Biochemical changes in Tomato plant by AM fungi. Annals of Plant Sciences 6.12 (2017) pp. 1926-1927.

Doi: http://dx.doi.org/10.21746/aps.2017.6.12.12

Source of support: Nil; Conflict of interest: Nil 